\title{
THEORY OF PLANNED BEHAVIOR APPLICATION ON MOTORCYCLE RIDER SAFETY BEHAVIOR
}

\author{
Jalaludin Jalaludin', Nunung Widyaningsih², Hermanto Dwiatmoko \\ ${ }^{1}$ Master of Civil Engineering, Mercu Buana University Jakarta, INDONESIA \\ ${ }^{2}$ Lecturer of Civil Engineering, Mercu Buana University Jakarta, INDONESIA \\ E-mail: a.jaalaludin@gmail.com
}

\begin{abstract}
In Indonesia, the basis for implementing road safety consists of five pillars which are compiled in the General National Road Safety Plan (RUNK). One of the pillars proclaimed is the behavior of safe road users. This aims as an effort to reduce traffic accidents because road users are the biggest factor in road accidents related to user behavior. The cases of road traffic accidents in Indonesia are dominated by motorcyclists, especially Jakarta, which is one of the cities with a fairly high rate of motorcycle accidents. Because the behavior of road users is closely related to traffic accidents, and also motorcyclists are the users who are involved in the highest traffic accidents, this study explains the factors that determine the safety behavior of motorcyclists in Jakarta. The application of the Theory of Planned Behavior (TPB) is used as a basis for finding the factors that may determine the behavior of the motorcyclist. Furthermore, the research approach used in this study is quantitative with primary data in the form of a closed questionnaire instrument from 230 respondents who ride motorcycles in Jakarta. The data analysis technique used is the Structural Equation Modeling (SEM) approach using the AMOS 22.00 program as a tool in determining the determinants of driver safety behavior. The results of the analysis show that the most dominant direct predictor in determining the safety behavior of motorcyclists in Jakarta is the intention to behave safely. While the indirect factor that determines is the attitude of the driver. The results of the analysis also show that the age of the driver has a significant influence on safety behavior.
\end{abstract}

Keywords: traffic accident; safety behavior; motorcyclist; theory of planned behavior; structural equation modeling.

\begin{tabular}{cccc}
\hline Received: & Revised: & Accepted: & Available online: \\
2021-12-02 & $2021-12-21$ & $2021-12-30$ & $2022-01-08$ \\
\hline
\end{tabular}

\section{INTRODUCTION}

Road safety today is an issue that has emerged and has become a global problem. Not only transportation issues, road safety also includes social aspects as evidenced by the idea of the Decade of Action for Road Safety 2011 - 2020 which was immediately declared by the United Nations (UN). In line with the United Nations, the Government of Indonesia through the Ministry of Transportation has prepared the General National Road Safety Plan (RUNK) for 2011 - 2035 with five safety pillars covering road safety management, safe roads, safe vehicles, safe road user behavior, and handling of post-accident victims as a guidelines for policy makers in planning and implementing road safety management. Safety is an effort made in order to overcome traffic accidents caused by various factors including human factors (Sujanto \& Mulyono, 2010).

Based on the report of the World Health Organization (WHO), traffic accidents are one of the causes of non-communicable deaths with the highest number (Suprobo, 2016). In Indonesia, deaths caused by road traffic accidents are dominated by motorbikes with the highest involvement reaching $61 \%$ and the areas of Jakarta, Bogor, Depok, Tangerang, and Bekasi have more than $70 \%$ mortality rates for motorbike riders (Dirjen Bina Marga, 2012). ). The data on road accidents in 2018 based on the report of the Indonesian Police Korlantas as much as $73.49 \%$ involved motorbikes in the Jakarta area becoming blood with a fairly high number of accidents (Agustina \& Lupita, 2019).

One of the previous theories on the causes of accidents is the Domino Heinrich theory which explains five factors that cause accidents and one of them is the human factor. The Warpani grouped the causes of traffic accidents including humans, vehicles, roads, and the environment (Enggarsasi $\&$ Sa'diyah, 2017). The percentage distribution of the causes of road traffic accidents in Indonesia is $93.52 \%$ of human factors, $2.77 \%$ of vehicle factors, $3.32 \%$ of road factors, and $0.49 \%$ of 
environmental factors (Marsaid et al., 2013). A previous study in the United Kingdom (UK), stated that there was a relationship between a driving style that has low accuracy and the risk of causing traffic accidents mediated by the relationship of driving speed (French et al., 1993) and drivers who smoke and drink alcohol will tend to engage in behaviors that risk causing traffic accidents (NguyenPhuoc et al., 2020). Driver's lifestyle also has a significant correlation on risky driving behavior and involvement in traffic accidents (Stanojević et al., 2020). Furthermore, driver behavior and driving style are aspects that are strongly related to traffic accidents (Sabbour \& Ibrahim, 2010) and the violation behavior shown while driving has a relationship with risk perception which is a significant predictor of motorcycle involvement in accidents (Cheng et al. , 2015). Thus, one of the factors that cause accidents is the behavior of unsafe drivers (Haryanto, 2016).

\section{Theory of Planned Behavior}

There are various theories that are commonly used in determining the factors that have an involvement in safety behavior in driving. One that is often used to explain road safety behavior is the Theory of Planned Behavior (TPB) (Ledesma et al., 2018). The TPB construct is also recommended as one of the theories that promote traffic behavior and safe behavior in crossing the road (Mostafavi et al., 2021). In addition, TPB also shows a function as a good predictor based on competitive behavioral intentions in driving ( $\mathrm{Li}$ et al., 2016). There is also a construct in the TPB, namely attitudes and subjective norms that have a positive relationship with the intention to use a seat belt while driving (Şimşekoğlu \& Lajunen, 2008). All components of TPB are significantly related to the intention to use a helmet as a safe driving behavior (Lajunen \& Räsänen, 2004) and in general, TPB is a predictor of intention to commit a violation with adaptive and interactive effects (Castanier et al., 2013).

Based on these previous studies, the TPB construct was used to find the factors that determine the safety behavior of motorcyclists in Jakarta. TPB consists of three independent constructs, namely attitudes, subjective norms, and perceived behavioral control and two dependent constructs including behavioral intentions and behavior (Ajzen, 1991). The components of the TPB are then adapted and adapted to safety behavior. The description of the TPB construct is shown in Figure 1. The hypotheses proposed based on Figure 1 are shown in Table 1.

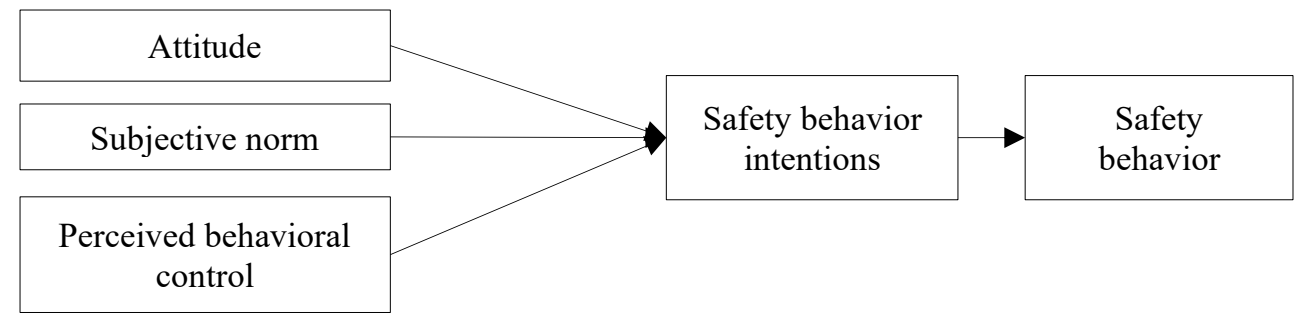

Figure 1. Construct Theory of Planned Behavior on Motorcycle Riders

Table 1. Construct Hypothesis Path

\begin{tabular}{clcl}
\hline Hypothesis & & Path & \\
\hline $\mathrm{H}_{1}$ & Attitude & $\rightarrow$ & Safety Behavior Intention \\
$\mathrm{H}_{2}$ & Subjective Norm & $\rightarrow$ & Safety Behavior Intention \\
$\mathrm{H}_{3}$ & Perceived Behavioral Control & $\rightarrow$ & Safety Behavior Intention \\
$\mathrm{H}_{4}$ & Safety Behavior Intention & $\rightarrow$ & Safety Behavior
\end{tabular}

The information obtained is based on Table 1 based on the TPB construct Figure 1, then the hypotheses in this study are (1) $\mathrm{H}_{1}$ attitude has a significant influence on safety behavior intention, (2) $\mathrm{H}_{2}$ subjective norm has a significant influence on safety behavior intention, (3) $\mathrm{H}_{3}$ perceived behavioral control has a significant influence on safety behavior intention, and (4) $\mathrm{H}_{4}$ safety behavior intention has a significant influence on safety behavior. 


\section{RESEARCH METHODS}

\section{Place and time of research}

The research location is Jakarta and the research time is May 2021 - July 2021.

\section{Method of collecting data}

The method used in the data collection process was the distribution of closed questionnaires which were distributed to 230 respondents who were motorcyclists in Jakarta. Thus, the data used is primary data. Furthermore, the measurement items used refer to the previous literature which is adapted to the context of safety behavior in motorcycle riding. The measurement items are shown in Table 2. The scale used for the measurement items is Likert with 7 levels of alternative answers. Level 1 is used for statements strongly disagree and level 7 for statements strongly agree. The reason for using the Likert scale is because it is more accurate in measuring self-regulated learning (SRL) than multiple choice (Retnawati, 2015), and SRL is the ability to be an active participant in metacognition, motivation, and behavior (Mukhid, 2008). Furthermore, the reason for using 7 levels is because 7 response points are preferred by respondents and have good validity, reliability, discrimination power, and stability (Budiaji, 2013).

Table 2. Constructs and Measurement Items

\begin{tabular}{|c|c|c|c|}
\hline Constructs & Code & Measurement items & Adaptation \\
\hline Atitude (ATD) & $\begin{array}{l}\text { ATD2 } \\
\text { ATD3 }\end{array}$ & $\begin{array}{l}\text { Using safety equipment while riding a motorcycle } \\
\text { is very safe. } \\
\text { Using safety gear while riding a motorcycle is a lot } \\
\text { of fun. } \\
\text { Using safety equipment while riding a motorcycle } \\
\text { is a commendable behavior }\end{array}$ & $\begin{array}{l}\text { Brijs et al. } \\
\quad(2014) \\
\text { Wang et al. } \\
\quad(2020)\end{array}$ \\
\hline $\begin{array}{c}\text { Subjective } \\
\text { Norms (SNR) }\end{array}$ & SNR1 & $\begin{array}{l}\text { The media influences me to behave safely in riding } \\
\text { a motorcycle. } \\
\text { The social environment influences me to behave } \\
\text { safely in riding a motorcycle. }\end{array}$ & $\begin{array}{l}\text { Castanier, } \\
\text { Deroche \& } \\
\text { Woodman } \\
\quad(2013) \\
\text { Wang et al. } \\
\quad(2020)\end{array}$ \\
\hline
\end{tabular}

\begin{tabular}{|c|c|c|c|}
\hline $\begin{array}{c}\text { Perceived } \\
\text { Behavioral } \\
\text { Control (PBC) }\end{array}$ & PBC1 & $\begin{array}{l}\text { I use an SNI helmet when riding a motorcycle even } \\
\text { though it is not a traffic order zone. } \\
\text { I have the resources needed to demonstrate safe } \\
\text { driving behavior. }\end{array}$ & $\begin{array}{c}\text { Brijs et al. } \\
\quad(2014) \\
\text { Wang et al. } \\
\quad(2020)\end{array}$ \\
\hline
\end{tabular}

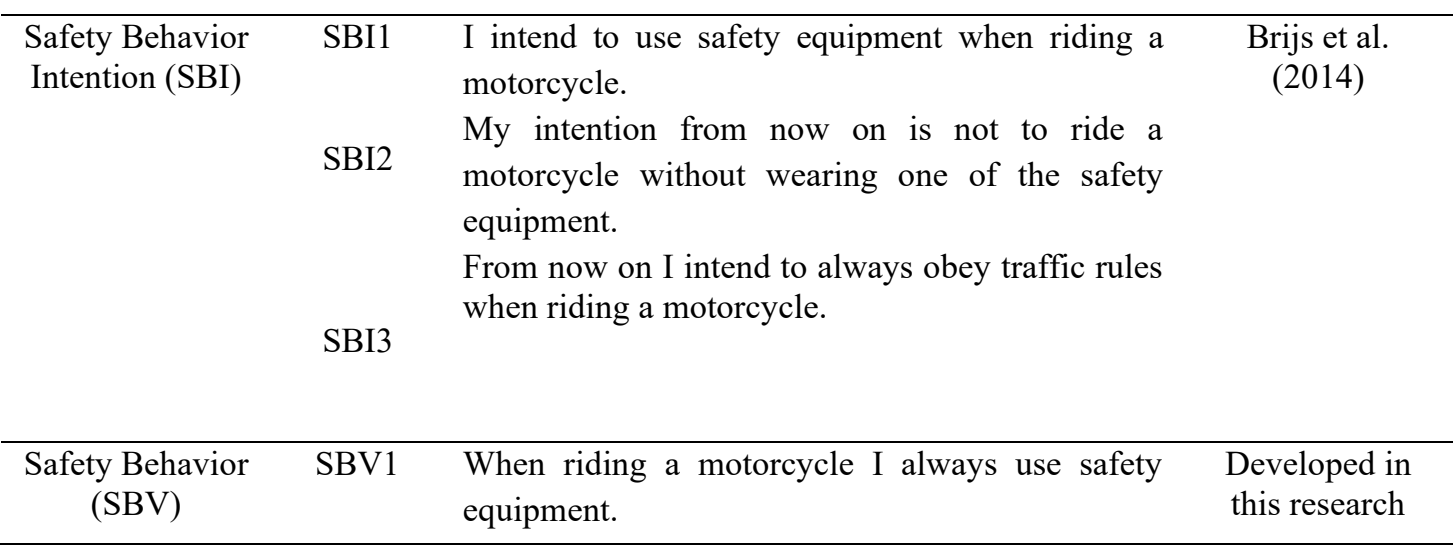


When riding a motorcycle I always obey traffic

SBV2 signs.

\section{Data processing}

In order to obtain the information needed in this study, a quantitative approach was used to measure the level of influence of the variables formed by the TPB construct based on Figure 1, measured based on Table 2, so that a score was obtained which was then processed with statistical data.

\section{Data analysis}

Structural Equation Modeling (SEM) was used as the basis for data analysis using the Analysis of Moment Structure (AMOS) 22.00 program. The SEM stages carried out in this study were Confirmatory Factor Analysis (CFA) for the construct to meet the Good of Fit Index (GOFI) criteria, and continued with hybrid SEM modeling with the maximum likelihood estimation technique.

\section{RESULTS AND DISCUSSION}

\section{Characteristics of Respondents}

The characteristics asked in the research questionnaire on 230 motorcycle riders in Jakarta and also the responses given are shown in Table 3. From these characteristics, there are 3 characteristics that are used as control variables for the type of dummy in SEM modeling including gender, age, and level of education. education.

Table 3. Characteristics of Respondents

\begin{tabular}{|c|c|c|c|}
\hline Caracteristic & Observer & Frequency $(n=230)$ & Percentage (\%) \\
\hline \multirow[t]{2}{*}{ Gender } & Man & 175 & 76,09 \\
\hline & Women & 55 & 23,91 \\
\hline \multirow[t]{3}{*}{ Age } & $<17$ & 1 & 0,43 \\
\hline & 17 - 35 years old & 197 & 85,65 \\
\hline & $35-55$ years old & 32 & 13,91 \\
\hline \multirow[t]{7}{*}{ Level of education } & No school & 1 & 0,43 \\
\hline & Primary school & 1 & 0,43 \\
\hline & Junior high school & 6 & 2,61 \\
\hline & Senior High School & 43 & 18,70 \\
\hline & Diploma & 21 & 9,13 \\
\hline & $\begin{array}{l}\text { Bachelor's } \\
\text { Degree/equivalent }\end{array}$ & 150 & 65,22 \\
\hline & $\begin{array}{l}>\text { Bachelor's } \\
\text { Degree/equivalent }\end{array}$ & 6 & 2,61 \\
\hline \multirow[t]{5}{*}{ Domicile } & Jakarta Barat & 43 & 18,70 \\
\hline & Jakarta Pusat & 17 & 7,39 \\
\hline & Jakarta Selatan & 46 & 20,00 \\
\hline & Jakarta Timur & 75 & 32,61 \\
\hline & Jakarta Utara & 13 & 5,65 \\
\hline
\end{tabular}




\begin{tabular}{llcc} 
& etc & 36 & 15,65 \\
\hline SIM Ownership & Don't have SIM C & 18 & 7,83 \\
& Own & 212 & 92,17 \\
\hline $\begin{array}{l}\text { Accident Involvement in } \\
\text { the Last 1 Year }\end{array}$ & 0 & 172 & 74,78 \\
& $1-3$ & 53 & 23,04 \\
& $>3$ & 5 & 2,17 \\
\hline
\end{tabular}

\section{Confirmatory Factor Analysis (CFA)}

The results of the CFA analysis in this study are shown in Table 4. In CFA, an analysis was also carried out to test the validity and reliability of the constructs using the standardized regression weights of the AMOS 22.00 output. Based on the information presented in Table 4, all TPB constructs have a standard loading value of 0.5 , which means that all constructs have good validity. Furthermore, for reliability, only attitude constructs and perceived behavioral control have a value slightly below the recommended 0.7 . As for the variance extracted, the construct that has a value slightly below the recommended 0.5 is the attitude construct and the intention of safe behavior. However, overall all constructs have quite good validity and reliability (Haryono, 2016).

Table 4. Results of CFA Analysis

\begin{tabular}{lcccc}
\hline \multicolumn{1}{c}{ Construct } & Items & $\begin{array}{c}\text { Standard } \\
\text { Loading }\end{array}$ & $\begin{array}{c}\text { Construct } \\
\text { reliability }\end{array}$ & $\begin{array}{c}\text { Variance } \\
\text { Extracted }\end{array}$ \\
\hline Attitude (ATD) & ATD1 & 0,639 & 0,667 & 0,402 \\
& ATD2 & 0,688 & \\
& ATD3 & 0,570 & & \\
\hline Subjective Norm (SNR) & SNR1 & 0,884 & 0,918 & 0,849 \\
& SNR2 & 0,957 & & \\
\hline Perceived Behavioral Control (PBC) & PBC1 & 0,712 & 0,533 \\
& PBC2 & 0,748 & & 0,492 \\
\hline Safety Behavior Intentions (SBI) & SBI1 & 0,622 & 0,704 & \\
& SBI2 & 0,589 & & 0,623 \\
& SBI3 & 0,831 & & \\
\hline Safety Behavior (SBV) & SBV1 & 0,877 & 0,765 & \\
\hline
\end{tabular}

\section{Hybrid Structural Equation Modeling (SEM)}

This analysis was carried out after the CFA process on the construct. Analysis of data processing was carried out with a conformity test referring to the GOFI criteria (Haryono, 2016) and statistical tests. The results of SEM modeling on the safety behavior of motorcyclists in Jakarta are illustrated in Figure 2. Furthermore, the results of the conformity test with AMOS 22.00 based on the SEM model in Figure 2 can be seen in Table 5. 


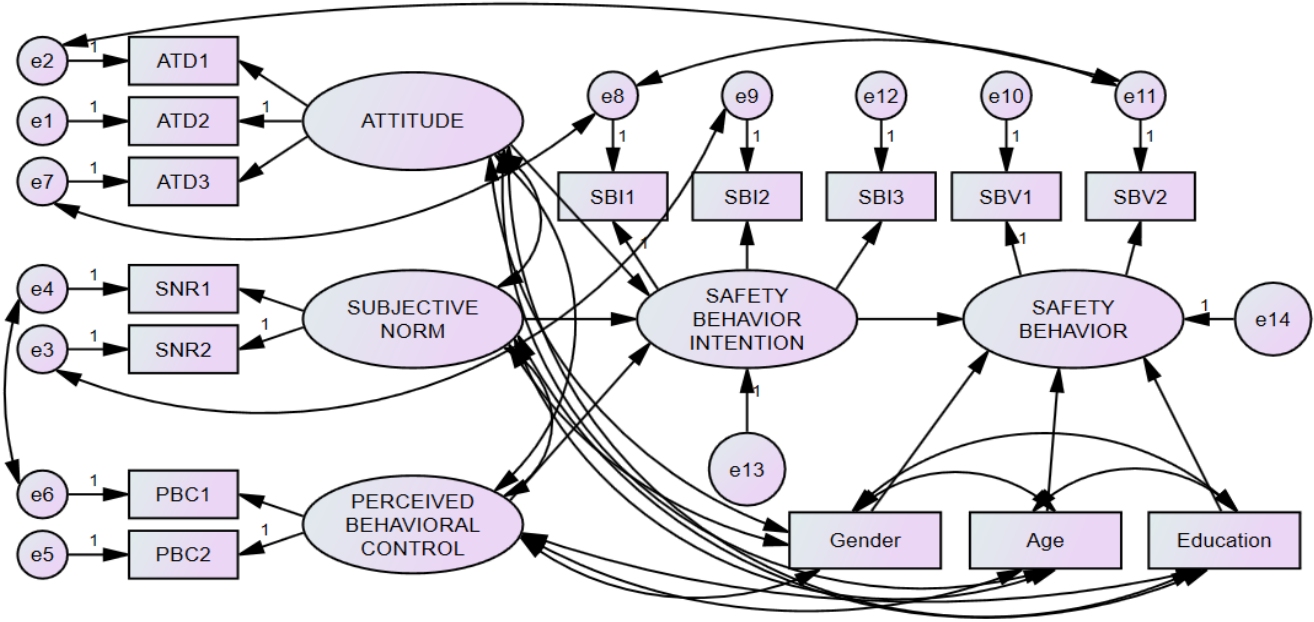

Figure 2. Structural Equation Modeling Motorcycle Rider Safety Behavior

Table 5. GOFI Test Results SEM Model

\begin{tabular}{lccc}
\hline \multicolumn{1}{c}{ GOFI } & Batasan & Hasil & Kriteria \\
\hline Chi square statistic $(\mathrm{p}=5 \%, \mathrm{df}=66)$ & $<85,964$ & 84,493 & Good of fit \\
\hline Significance probability & $\geq 0,05$ & 0,062 & Good of fit \\
\hline CMIN/DF & $\leq 2,00$ & 1,28 & Good of fit \\
\hline Goodness of index (GFI) & $\geq 0,90$ & 0,956 & Good of fit \\
\hline Adjusted goodness fit index (AGFI) & $\geq 0,90$ & 0,919 & Good of fit \\
\hline Tucker lewis index (TLI) & $\geq 0,95$ & 0,980 & Good of fit \\
\hline Comparative fit index (CFI) & $\geq 0,95$ & 0,967 & Good of fit \\
\hline The Root mean square error of approximation (RMSEA) & $\leq 0,08$ & 0,035 & Good of fit \\
\hline
\end{tabular}

\section{Direct and Indirect Influence}

Based on the structural model that has met the GOFI criteria in Figure 2, in order to find information on the variables that have the most dominant influence on safety behavior, it is by reviewing the output results at AMOS 22.00. This influence analysis aims to see how strong the influence of one variable on other variables is either directly or indirectly. The interpretation of the results of this influence analysis is meaningful for determining a clear strategy in improving the behavior of road users who are safe, especially motorcycle riders. The findings of the analysis of direct and indirect effects are shown in Table 6 and Table 7.

The findings of the analysis in Table 6, the variable that became the most dominant predictor in influencing the safety behavior of motorcyclists was the intention to behave safely with a statistical value of 0.619. Furthermore, the variable that has a dominant influence on the intention of safe behavior is the attitude of the driver. Table 7 shows that the dominant variable that has an indirect influence on safety behavior is the attitude of the driver. The other variable which also has a positive influence indirectly is subjective norm.

Table 6. Results of Direct Effect Analysis

\begin{tabular}{lrrrrr}
\hline & PBC & SNR & ATD & SBI & SBV \\
\hline Safety Behavior Intention &,- 023 &, 062 &, 546 &, 000 &, 000
\end{tabular}




\begin{tabular}{lccccc}
\hline & PBC & SNR & ATD & SBI & SBV \\
\hline Safety Behavior &, 000 &, 000 &, 000 &, 619 &, 000 \\
\hline
\end{tabular}

Table 7. Results of Indirect Influence Analysis

\begin{tabular}{lccccc}
\hline & PBC & SNR & ATD & SBI & SBV \\
\hline Safety Behavior Intention &, 000 &, 000 &, 000 &, 000 &, 000 \\
\hline Safety Behavior &,- 014 &, 038 &, 338 &, 000 &, 000 \\
\hline
\end{tabular}

Table 8 shows the influence of the respondent's characteristics which are used as control variables in modeling based on the Critical Ratio (C.R) and Probability (P) values including gender, age, and education. Based on the $\mathrm{P}$ value, only the age variable has a significant influence on safety behavior because it has a $\mathrm{P}$ value 0.05 (Haryono, 2016) while gender and education are not significant. The C.R value on the age variable is negative. The meaning of the negative value when associated with a dummy aged $<35$ years (value 1 ) and a dummy aged $>35$ years (score 0 ) is that the behavior of drivers aged $>35$ years shows more safe driving behavior than drivers aged $<35$ years. The negative $\mathrm{CR}$ value is also owned by the sex control variable which is significant if it is associated with the male gender dummy (value 1) and the female gender dummy (value 0) is that female drivers show more safe driving behavior than female drivers. man. Furthermore, the education variable also has a negative C.R value and if it is associated with a dummy of education above high school (value 1) and a dummy of high school education or lower (value 0) informs that the behavior in driving is safer shown by respondents with a high school education or lower. Thus, the level of education does not guarantee safe driving behavior.

Table 8. Results of Analysis of CR and P Control Variables

\begin{tabular}{|c|c|c|c|c|c|}
\hline \multicolumn{3}{|c|}{ Path } & \multirow{2}{*}{$\begin{array}{c}\text { C.R } \\
-1,951\end{array}$} & \multirow{2}{*}{$\begin{array}{c}\mathbf{P} \\
0,051\end{array}$} & \multirow{2}{*}{$\begin{array}{c}\text { Description } \\
\text { Not significant }\end{array}$} \\
\hline Gender & $\rightarrow$ & Safety Behavior & & & \\
\hline Age & $\rightarrow$ & Safety Behavior & $-2,282$ & 0,026 & Significant \\
\hline Education & $\rightarrow$ & Safety Behavior & $-0,125$ & 0,900 & Not significant \\
\hline
\end{tabular}

\section{Hypothesis Test Results}

Testing of the 4 hypotheses proposed in Table 1 is to use a t-value and a significance level of $5 \%$. The t-value in the AMOS 22.00 program is the Critical Ratio (C.R) value of the fit model that has been accepted or has met the GOFI test. The research hypothesis is accepted if it has a C.R value 1.957 and a probability (P) 0.05 (Haryono, 2016). The results of the analysis of hypothesis testing by AMOS 22.00 based on the fit model in Figure 2 are shown in Table 9.

Table 9. Hypothesis Test Results

\begin{tabular}{|c|c|c|c|c|c|c|}
\hline & \multicolumn{3}{|c|}{ Path } & C.R. & $\mathbf{P}$ & Results \\
\hline $\mathrm{H}_{1}$ & $\begin{array}{l}\text { Attitude has a significant } \\
\text { influence on safety } \\
\text { behavior intention }\end{array}$ & & $\begin{array}{l}\text { Safety Behavior } \\
\text { Intention }\end{array}$ & 4,701 & $* * *$ & Received \\
\hline $\mathrm{H}_{2}$ & $\begin{array}{l}\text { Subjective norms has a } \\
\text { significant influence on } \\
\text { safety behavior intention }\end{array}$ & $\rightarrow$ & $\begin{array}{l}\text { Safety Behavior } \\
\text { Intention }\end{array}$ & 0,807 & 0,420 & Rejected \\
\hline $\mathrm{H}_{3}$ & $\begin{array}{l}\text { Perceived behavioral } \\
\text { control has a significant } \\
\text { influence on safety } \\
\text { behavior intention }\end{array}$ & & $\begin{array}{l}\text { Safety Behavior } \\
\text { Intention }\end{array}$ & $-0,247$ & 0,805 & Rejected \\
\hline
\end{tabular}




\begin{tabular}{clllll}
\hline $\mathrm{H}_{4} \quad \begin{array}{l}\text { Safety behavior intention } \\
\text { has a significant } \\
\text { influence on safety } \\
\text { behavior }\end{array}$ & $\rightarrow$ Safety Behavior & 6,863 & $* * *$ & Received \\
\hline The value of $* * *$ in P indicates 0 & & & & \\
\hline
\end{tabular}

The value of $* * *$ in $\mathrm{P}$ indicates 0

The information obtained based on Table 9 shows that there are accepted hypotheses and rejected hypotheses. The accepted research hypothesis is $\mathrm{H} 1$ which states that attitude has a significant influence on the intention of safe behavior, and $\mathrm{H} 4$ which states that the intention of safe behavior has a significant influence on safety behavior.

\section{CONCLUSION}

There are various ways that can be done to reduce the rate of road traffic accidents involving motorcyclists and one of them is to demonstrate safe driving behavior. This study found the factors that determine the safety behavior of motorcyclists in Jakarta based on the construct of TPB. The findings of the analysis show that the intention of survival behavior is the most dominant predictor in determining survival behavior directly. The attitude is an indirect determining factor in showing safe behavior while driving. Another finding is that the age of the driver has a significant effect on safety behavior. The model of the TPB construct applied in this study is not fully accepted, however, the TPB construct has a predictor as a determinant of the safety behavior of motorcyclists.

\section{REFERENCES}

Agustina, \& Lupita. 2019. Faktor-Faktor Yang Berhubungan dengan Tingkat Kelelahan Kerja pada Pengemudi Ojek Online di Wilayah Jakarta Timur Tahun 2019. Jurnal Persada Husada Indonesia, 6(23), 25-36. (Indonesian).

Ajzen, I. 1991. The theory of planned behavior. Organizational Behavior and Human Decision Processes, 50(2), 179-211. https://doi.org/10.1016/0749-5978(91)90020-T

Brijs, K., Brijs, T., Sann, S., Trinh, T. A., Wets, G., \& Ruiter, R. A. C. 2014. Psychological determinants of motorcycle helmet use among young adults in Cambodia. Transportation Research Part F: Traffic Psychology and Behaviour, 26(PA), 273-290. https://doi.org/10.1016/j.trf.2014.08.002

Budiaji, W. 2013. Skala Pengukuran dan Jumlah Respon Skala Likert (The Measurement Scale and The Number of Responses in Likert Scale). Ilmu Pertanian Dan Perikanan, 2(2), 127-133. (Indonesian).

Castanier, C., Deroche, T., \& Woodman, T. 2013. Theory of planned behaviour and road violations: The moderating influence of perceived behavioural control. Transportation Research Part F: Traffic Psychology and Behaviour, 18(2013), 148-158. https://doi.org/10.1016/j.trf.2012.12.014

Cheng, A. S. K., Liu, K. P. Y., \& Tulliani, N. 2015. Relationship between driving-violation behaviours and risk perception in motorcycle accidents. Hong Kong Journal of Occupational Therapy, 25, 32-38. https://doi.org/10.1016/j.hkjot.2015.06.001

Dirjen Bina Marga, 2012. Panduan Teknis 1 Rekayasa Keselamatan Jalan. Jakarta: Kementerian Pekerjaan Umum Republik Indonesia. (Indonesian).

Enggarsasi, U., \& Sa'diyah, N. K. 2017. Kajian terhadap Faktor-Faktor Penyebab Kecelakaan Lalu Lintas dalam Upaya Perbaikan Pencegahan Kecelakaan Lalu Lintas. Perspektif, 22(3), 238-247. https://doi.org/10.30742/perspektif.v22i3.632. (Indonesian).

French, D. J., West, R. J., Elander, J., \& Wilding, J. M. 1993. Decision-making style, driving style, and self-reported involvement in road traffic accidents. Ergonomics, 36(6), 627-644. https://doi.org/10.1080/00140139308967925

Haryanto, H. 2016. Keselamatan Dalam Berkendara: Kajian Terkait Dengan Usia Dan Jenis Kelamin Pada Pengendara. Inquiry, 7(2), 231153. (Indonesian).

Haryono, S., 2016. Metode SEM: AMOS, LISREL, PLS. Jakarta: PT. Intermedia Personalia Utama. 
Lajunen, T., \& Räsänen, M. 2004. Can social psychological models be used to promote bicycle helmet use among teenagers? A comparison of the Health Belief Model, Theory of Planned Behavior and the Locus of Control. Journal of Safety Research, 35(1), 115-123. https://doi.org/10.1016/j.jsr.2003.09.020

Ledesma, R. D., Tosi, J. D., Díaz-Lázaro, C. M., \& Poó, F. M. (2018). Predicting road safety behavior with implicit attitudes and the Theory of Planned Behavior. Journal of Safety Research, 66, 187-194. https://doi.org/10.1016/j.jsr.2018.07.006

Li, P., Shi, J., Liu, X., \& Wang, H. 2016. The Theory of Planned Behavior and Competitive Driving in China. Procedia Engineering, 137, 362-371. https://doi.org/10.1016/j.proeng.2016.01.270

Marsaid, Hidayat, M., \& Ahsan. 2013. Faktor yang Berhubungan dengan Kejadian Kecelakaan Lalu Lintas pada Pengendara Sepeda Motor di Wilayah Polres Kabupaten Malang. Jurnal Ilmu Keperawatan, 1(2), 98-112. https://doi.org/http://dx.doi.org/10.11606/issn.2176-7262.v49i5p475482. (Indonesian).

Mostafavi, F., Nasirian, M., Zeinali, M., Ardalan, G., Mohebpou, F., Daniali, S. S., Pirzadeh, A., \& Kelishadi, R. 2021. Evaluating Community-Based Programs in Promoting Traffic Behaviors and Safe Road Crossing Behaviors in Youth: An Application on Theory of Planned Behavior. International Journal of Preventive Medicine, 12. https://doi.org/10.4103/ijpvm.IJPVM_241_20

Mukhid, A. 2008. STRATEGI SELF-REGULATED LEARNING (Perspektif Teoritik). Tadris, 3(2), 222-239.

Nguyen-Phuoc, D. Q., Oviedo-Trespalacios, O., Nguyen, T., \& Su, D. N. 2020. The effects of unhealthy lifestyle behaviours on risky riding behaviours - A study on app-based motorcycle taxi riders in Vietnam. Journal of Transport and Health, 16(January), 100666. https://doi.org/10.1016/j.jth.2019.100666

Retnawati, H. 2015. The Comparison of The Accuracy of Likert Scale. Jurnal Kependidikan: Penelitian Inovasi Pembelajaran, 45(2), 156-167.

Sabbour, S. M., \& Ibrahim, J. M. 2010. Driving behaviour, driver style and road traffic accidents among young medical group. Injury Prevention, 16(Supplement 1), A33-A33. https://doi.org/10.1136/ip.2010.029215.120

Şimşekoğlu, Ö., \& Lajunen, T. 2008. Social psychology of seat belt use: A comparison of theory of planned behavior and health belief model. Transportation Research Part F: Traffic Psychology and Behaviour, 11(3), 181-191. https://doi.org/10.1016/j.trf.2007.10.001

Stanojević, D., Stanojević, P., Jovanović, D., \& Lipovac, K. 2020. Impact of riders' lifestyle on their risky behavior and road traffic accident risk. Journal of Transportation Safety and Security, 12(3), 400-418. https://doi.org/10.1080/19439962.2018.1490367

Sujanto, S., \& Mulyono, A. T. 2010. Inspeksi Keselamatan Jalan Di Jalan Lingkar Selatan Yogyakarta. Jurnal Transportasi, 10(1), 13-22. (Indonesian).

Suprobo, Y. 2016. ANALISIS PERUBAHAN PERILAKU BERKENDARA PADA PENGEMUDI ANGKUTAN UMUM PENUMPANG. Jurnal Penelitian Transportasi Darat, 18(2), 117-132. https://doi.org/10.1017/CBO9781107415324.004. (Indonesian).

Wang, X., Yuen, K. F., Shi, W., \& Ma, F. 2020. The determinants of passengers' safety behaviour on public transport. Journal of Transport and Health, 18(February), 100905. https://doi.org/10.1016/j.jth.2020.100905 